\title{
Seed Deterioration in Barley Seed Under Accelerated Aging Test
}

\author{
Burcu Begüm Kenanoğlu ${ }^{1^{*}} \quad$ Nurdoğan Topal $^{2} \quad$ Sinem Tuğçe Cin ${ }^{3}$
}

\author{
${ }^{1:}$ Uşak University, Faculty of Agriculture and Natural Science, Horticulture Department, Uşak, Turkey \\ 2: Uşak University, Faculty of Agriculture and Natural Science, Field Plants Department, Uşak, Turkey \\ ${ }^{3:}$ Uşak University, Science Institute, Agriculture Science department, Uşak /Turkey \\ *Corresponding Author: burcu.kenanoglu@usak.edu.tr
}

Geliş Tarihi: 18.07.2019

Kabul Tarihi: 23.10.2019

\begin{abstract}
Seed deterioration is considered to begin at physiological maturity and continues during harvesting and storage. It's influenced by genetic, production and environmental factors. Genetic differences are between cultivars for the ability to sustain good seed quality in nonsuitable environments. The study aim was to determine the seed deterioration of Hordeum vulgare L. seed lots with accelerated aging tests in three different periods. Seven different proprietary barley varieties used in the study were obtained from Aegean Agricultural Research Institute (İzmir/Turkey). Our methods which used for this purpose; at $30{ }^{\circ} \mathrm{C}(7$ day) germination and seedling test, accelerated aging test with $24-48$ and 72 hours at $45^{\circ} \mathrm{C}$ and $\mathrm{EC}$ test at $20{ }^{\circ} \mathrm{C}$ in $24-48-72$ hours were made. Observations made at the end of the treatments; seed moisture content (\%), normal-abnormal germination rate (\%), mean germination time (day). The germination rates of varieties are close to each other and very high. However, at the end of the vigor test of the aged cultivars, significant differences were observed especially in the mean germination time and seedling emergence performance. In EC measurement results, the best value was taken from Sancak variety.
\end{abstract}

Keywords: Hordeum vulgare, germination rate, accelerated aging test, electrical conductivity, genotypes

\section{Hızlı Yaşlandırma Testi Koşulları Altında Arpa Tohumlarında Bozulma $\ddot{\mathrm{O} z}$}

Tohumda bozulma fizyolojik olgunlukta başlar, hasat ve depolama sırasında devam etmektedir. Bu durum genetik, üretim ve çevresel faktörlerden etkilenir. Uygun olmayan ortamlarda iyi tohum kalitesini sürdürebilmek, çeşitler arasındaki genetik farklılıklar ile mümkündür. Bu çalışmanın amacı, üç farklı periyotta hızlandırılmış yaşlanma testleriyle Hordeum vulgare L. tohum lotlarının tohum bozulma durumlarını belirlemektir. Araştırmada kullanılan yedi farklı tescilli arpa çeşidi İzmir Ege Tarımsal Araştırma Enstitüsü'nden temin edilmiştir. Bu amaçla kullanılan yöntemlerimiz; $30{ }^{\circ} \mathrm{C}$ 'de (7 gün) çimlenme ve fide testinde, 24-48 ve 72 saatte $45{ }^{\circ}{ }^{\circ}$ 'de yaşlanma testi ve $20{ }^{\circ}{ }^{\circ}$ 'de $24-48-72$ saatte EC testi yapılmıştır. Çalışmamızın sonunda yapılan gözlemler; tohum nem içeriği (\%), normal anormal çimlenme oranı (\%), ortalama çimlenme süresi (gün) ve elektriksel kondaktivite değeri $(\mu \mathrm{S} / \mathrm{cm})$ dir. Çeşitlerin çimlenme oranları birbirine yakın ve çok yüksektir. Bununla birlikte, güç testi sonucunda yaşlandırılmış çeşitlerin, özellikle ortalama çimlenme süreleri ve fide çıkış performanslarında önemli farklılıklar gözlenmiştir. EC ölçüm sonuçlarında en iyi değer Sancak çeşidinden alınmıştır.

Anahtar Kelimeler: Hordeum vulgare, çimlenme oranı, hızlı yaşlandırma testi, elektriksel kondaktivite, genotipler

\section{Introduction}

Cereals, which are the most important source of human and animal nutrition, is the product group which is mostly cultivated and produced most in the world. Most of the foods consumed by people in their daily diets are composed of vegetable-based foods. Almost $66 \%$ of these are composed of cereals (Ergutay and Elgün, 1995). Barley, which is the main plants cultivated in the world history, has been used in human nutrition for thousands of years. The findings uncovered the archaeological excavations done in the early 1900s have revealed that barley was grown also in 3000s B.C. It is known that its culture is very old also in Anatolia territory and its homeland is the geographical region named as "Fertile Crescent" including the countries such as Israel, Jordan, Palestine, Syria, Iraq, and Iran and covering also Turkey (Harlan and Zoharry, 1966; Gökgöl, 1969; Nesbitt and Samuel, 1995). Barley is one of the plants that was first cultivated by people in order to meet the basic food needs and has a high adaption capability (Allard and Bradshaw, 1964). Barley, that takes the second place after wheat among the cool climate cereals with the cultivation area of 2.8 ha and the production of 8 
million tons in Turkey, is mostly consumed as animal feed and the raw material of malt industry. Barley production areas have decreased $19.1 \%$ in the last 23 years in Turkey, the increase in yield specified in the other products could not be achieved (TÜIK, 2015). In the world, the barley production area was 55 million hectares in 2001 but decreased to 46 million hectares in 2016. The worldwide barley production amount was 140 million tons in 2001 and was 141 million tons in 2016 (FAO, 2018).

Barley takes the $4^{\text {th }}$ place after wheat, maize, and paddy, that are mostly produced cereals in the world and takes the second place among the cool climate cereals. In Turkey, the barley cultivation area was about 36 million decares in 2001; however, this area deceased to 24 million decares in 2017. The production amount was approximately 8 million tones in 2001 and it was 7 million in 2017 (TÜİK, 2018).

Today, $65 \%$ of the barley produced is used in feed industry, $33 \%$ in beer industry and biodiesel production, $2 \%$ in the food industry. It is used for producing bread, biscuits, cracker, tea, and infant formula. Due to its high digestible fiber rate and high $\beta$-glucan content, the use of barley as barley meal has increased in some countries and it has gained importance in human nutrition (Baik and Ulrich, 2008; Ergun et al., 2012). It meets raw material needed in the malt industry including animal feed and beer and it gives the opportunity to cultivate the second crop as it is harvested earlier than wheat. Its use in the food and beer industries is lower compared to animal husbandry and it increases each year regularly ( Demir, 1983; Kün, 1988; Sencar and Gökmen 1997; Forster et al., 2000; Schulte et al., 2009).

Seed vigor is described as "general total of the seed characteristics that determine the activity and performance of a seed during germination and seedling emergence". The losses in the seed vigor is related with the decrease in fulfilling all the physiological functions of the seed. This process called as physiological aging starts before harvest and continues during harvest, processing and storage. The ending point of this deterioration is the death of the seed, that is, the complete loss of germination. However, before seeds lose their germination ability, they lose their vigor. Therefore, the physiological age difference of the seed lots with similar high germination values (degree of deterioration) and thus the differences in seed vigor occur. These seed vigor differences are observed in the seed lots of the species of garden plants, field crops and forest plants (Sivritepe, 2012). Seed deterioration may be described as the vigor, viability and quality loss due to the effect of negative environmental factors or aging.

The changes in enzyme activity and the decrease of seedling growth rate are the results of seed deterioration. Accelerated aging techniques have a great potential in understanding the relationship between the aging and the deterioration mechanisms of seeds (McDonald, 1999). In this study, some accelerated aging methods were used in barley (Hordeum vulgare L.) cultivars and their performances were revealed.

\section{Material and Method}

Seven barley (Hordeum vulgare L.) genotypes (Troya, Akhisar, Bayrak, Hilal, Börgüt, Sancak, EgeBeyi) obtained from Aegean Agricultural Research Institute (İzmir/Turkey) were used in this study. Accelerated aging vigor test, electrical conductivity test, protein analysis and germinationemergence tests were performed in different genotypes.

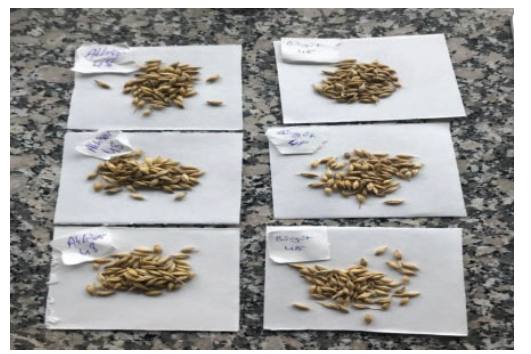

Image1. Seeds of barley used in the experiment

Moisture content calculation: 
Seed moisture of each lot was determined according to the rules of ISTA (International Seed Test Association) (1995). Initial weights of $1 \mathrm{~g}$ of 2 replicated seed samples were weighed. Then the seeds were kept at $130^{\circ} \mathrm{C}$ for 1 hour to determine the final weight of the seeds. At the end of this period, the seeds were removed from the oven and kept in the desiccator for half an hour with their mouths closed in order to cool the seeds and their final weights were weighed (ISTA, 1995).

Germination and emergence tests:

In this study, $3 * 25$ seeds / repeats were subjected to petri germination for 7 days at $30{ }^{\circ} \mathrm{C}$ and viol output tests for 21 days (ISTA, 1995).

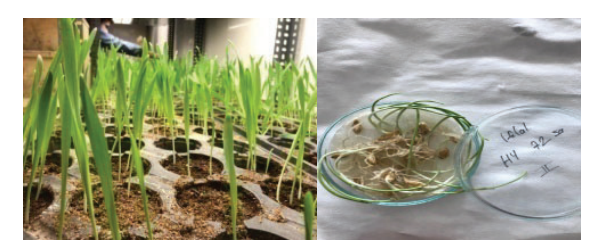

Image 2. Germination and emergence tests

Accelerated aging vigor test:

In this study, $3 * 25$ seeds / repetitions were subjected to aging at $45{ }^{\circ} \mathrm{C}$ for 24,48 and 72 hours. Then it was taken to petri germination at $25{ }^{\circ} \mathrm{C}$ for 15 days.

Electrical conductivity (EC)

$3 * 100$ seeds / repeat were measured at EC meter $(\mu \mathrm{S} / \mathrm{cm})$ at $20{ }^{\circ} \mathrm{C}$ for 24,48 and 72 hours.

Mean germination time (MGT)

Mean germination time calculation:

In formula;

$$
\mathrm{MGT}=\frac{\Sigma \mathrm{n} \cdot \mathrm{D}}{\Sigma \mathrm{n}}
$$

MGT: Mean germination time

$\mathrm{n}$ : D. day germinated seed number

D: It refers to the day since the beginning of germination.

Protein analysis

The crude protein $(\mathrm{CP})$ values of the seed lots was determined using Kjeldahl method for total $\mathrm{N}$ as stated in AOAC (1998).

a. Wet digestion:

0.5 of the seed sample, ground to sift out from a sieve of $1 \mathrm{~mm}$, was weighed and put in kjeldahl flask and after adding $15 \mathrm{ml}$ of $98 \%$ sulfuric acid and 1 kjeldahl tablet, the flasks were placed in the wet digestion part of kjeldahl device. The heater of the device was operated and it was heated up to $410{ }^{\circ} \mathrm{C}$ by increasing gradually and the heating process was continued at a constant temperature of $410{ }^{\circ} \mathrm{C}$ until the content of the flask acquired a clear greenish color. The vacuum system was also operatedsynchronously with operation of the heater in order to remove $\mathrm{H}_{2} \mathrm{SO}_{4}$, that evaporated during boiling. After acquiring the wanted clear greenish color, the device was turned off and the flasks was left to cool.

b. Distillation:

The flasks cooled after wet digestionwas diluted with $50-60 \mathrm{ml}$ of distilled waterand transferred into the big flasks of the distillation device and placed into the distillation device. Distillation was performed in a fully-automated device. $60 \mathrm{ml}$ of $40 \% \mathrm{NaOH}$ was used. It was placed in the collecting part of the erlenmeyer device which contained $25 \mathrm{ml}$ of $4 \%$ boric acid and in which the distillate was gathered and the distillation process was continued until the distillate became $150 \mathrm{ml}$. 


\section{c. Titration:}

Titration was performed with $0.1 \mathrm{~N} \mathrm{HCl}$.The $\mathrm{HCl}$ amount used in titration was stated in $\mathrm{ml}$. Calculation was performed as follows:

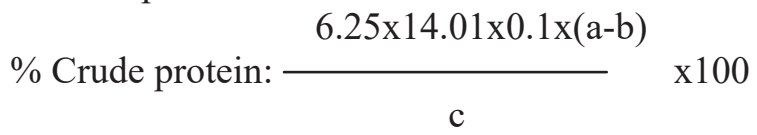

a:HCI amount consumed in titration, $\mathrm{ml}$ $\mathrm{b}: \mathrm{HCI}$ amount consumedin titration in blank trial, $\mathrm{ml}$ c:HCI concentration used $(\mathrm{N})$

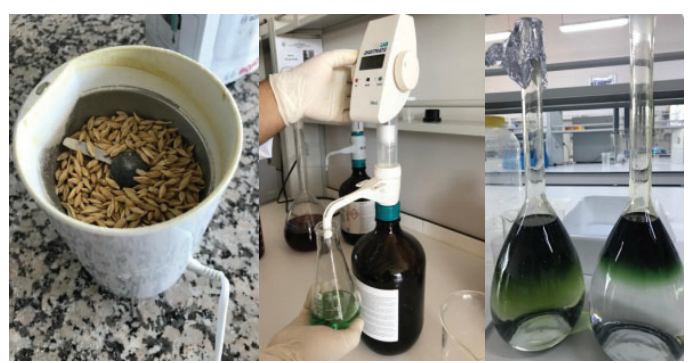

Image 3. Protein analyses

\section{Results}

- Moisture Contents of the Cultivars

The moisture values of the genotypes were found to be between $7.6-10.2 \%$.

\section{- Findings of Germination Test}

The findings obtained in Petri tests were subjected to analysis of variance and a very significant difference $(\mathrm{p}>0.01)$ was determined among Time, Cultivar,and Interactions (time*cultivar). The treatments with the fastest emergence in MGT (Mean Germination Time) parameter after the Duncan's multiple comparisons were control and 24-hour treatments and they were included in "c" group. Control and 24-hour treatmentsalso had the highest rate in terms of \% germination parameters of $2^{\text {nd }}$ day and they were included in "a-ab" groups (graph 1).

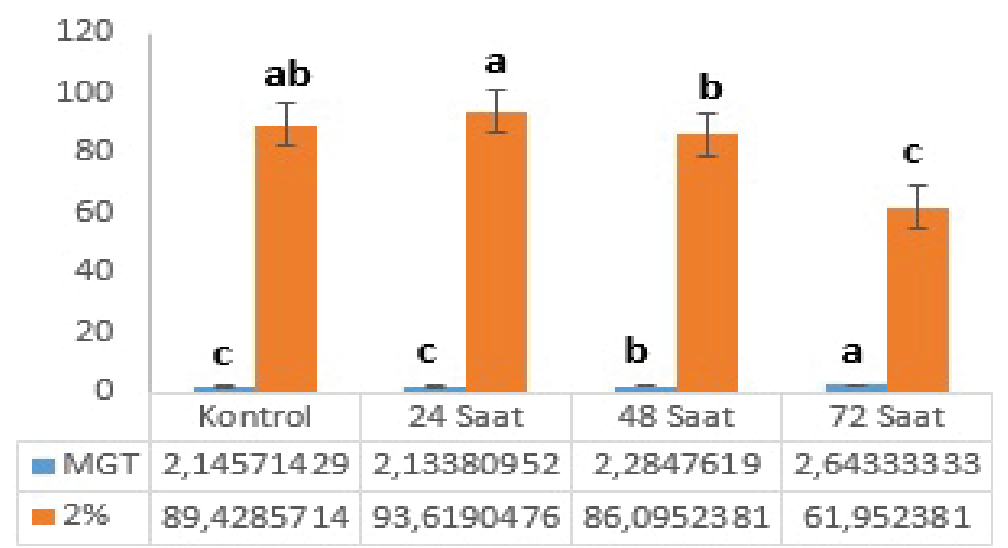

Graph 1. MGT and 2.day Germination of Barley Seeds According to Aging Time (\%)

In Duncan's multiple comparison, when the cultivars were compared, Sancak (d) cultivar had the lowest value in terms of MGT, which was followed by Troya cultivar and they were included in "bc" group. Hilal cultivar had the highest value and was included in "a" group.Sancak cultivar also was the first in \% germination parameter of $2^{\text {nd }}$ day and it was included in "a" group and Hilal cultivar had the lowest rate and was included in "d" group (graph 2). 


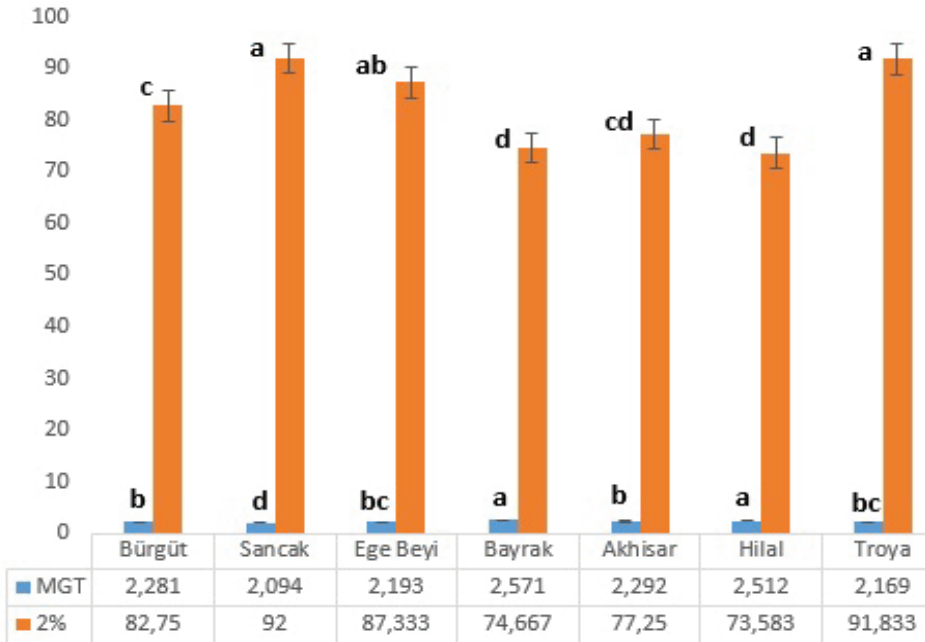

Graph 2. MGT and 2.day Germination rates according to barley varieties (\%)

- Findings of Viol Test

Findings of viol tests were subjected to analysis of variance and a very significant statistical difference ( $p>0.01)$ was determined among time applications in $\%$ germination parameter of $2^{\text {nd }} d a y$ and no significant difference was determined in mean emergence time (MET) parameter $(p>0.05)$. When the cultivars were examined, a very significant difference $(p>0.01)$ was determined among cultivars in terms of $\%$ germination and MET parameters of $2^{\text {nd }}$ day.

After the Duncan's multiple comparison performed between time applications, Control Time application had the best result in \% germination parameterof $2^{\text {nd }}$ day and it was included in "a" group.48- and 78- hour treatments had the worst result among the treatments. In MET parameter, Control and 24-hour treatments had the lowest values as expected and they were included in "b" group (graph 3).

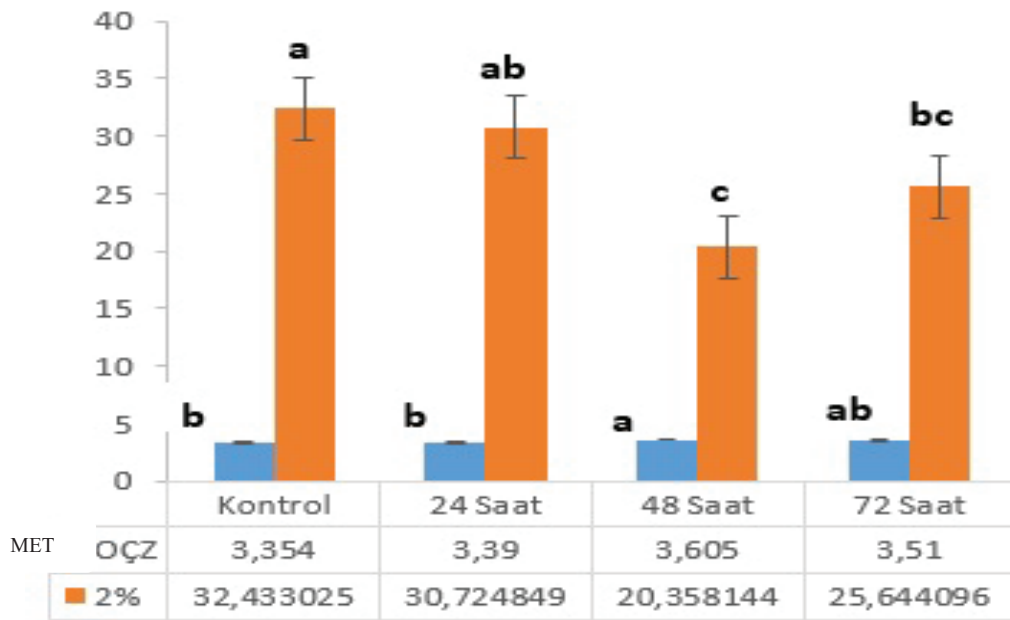

Graph 3. Barley Seeds MET and 2. day Emergence Rates according to Aging Time\%

When the cultivars were compared, Börgüt and Troya cultivars had good performances in \% germination parameter of $2^{\text {nd }}$ day than Bayrak and Hilal cultivars. When MET was assessed, Börgüt and Sancak cultivars had the best expected values. As no data was obtained from Hilalcultivar, the transformed MET data made a difference in grouping (graph 4). 


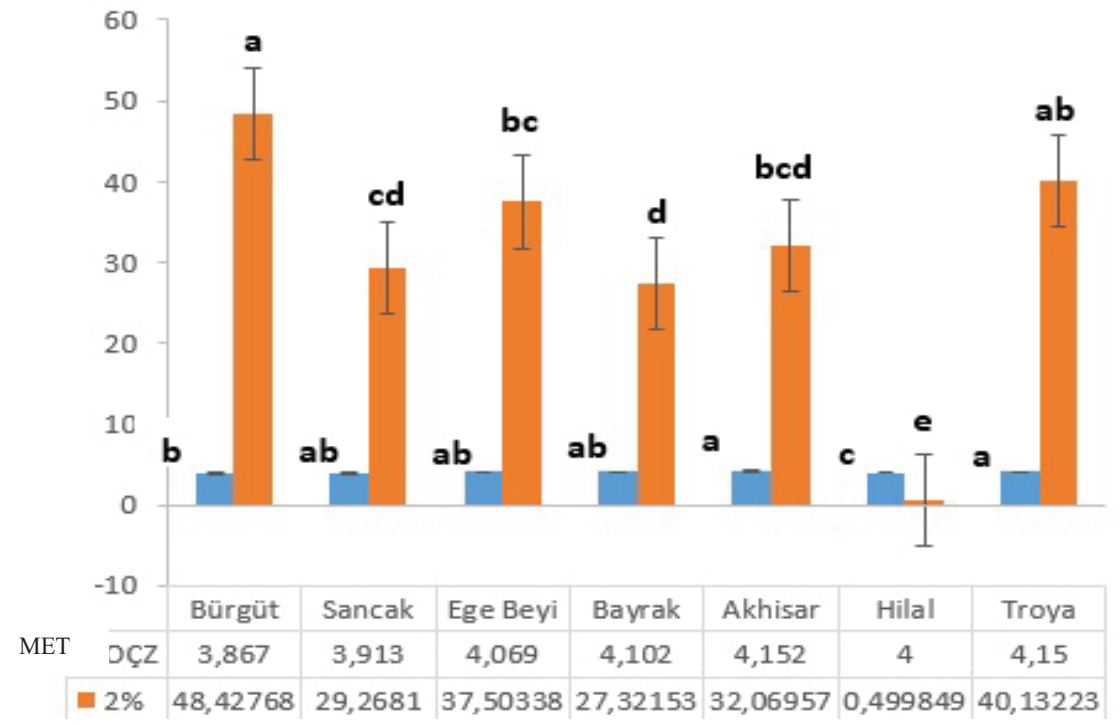

Graph 4. MET and 2. day emergence rates according to barley varieties (\%)

\section{- Electrical Conductivity (EC)}

EC test, one of the vigor tests, was applied for the cultivars and a very significant difference ( $>0.01)$ was determined between the cultivars after the analysis of variance. As the seed viability and EC values were inversely proportional, Sancak cultivar having the lowest mean value as a result of the statistical analysis (Duncan) was included in "f" group and it had the best value. Ege Beyi cultivar, with the highest mean value, had the highest EC value and was included in "a" group (graph 5).

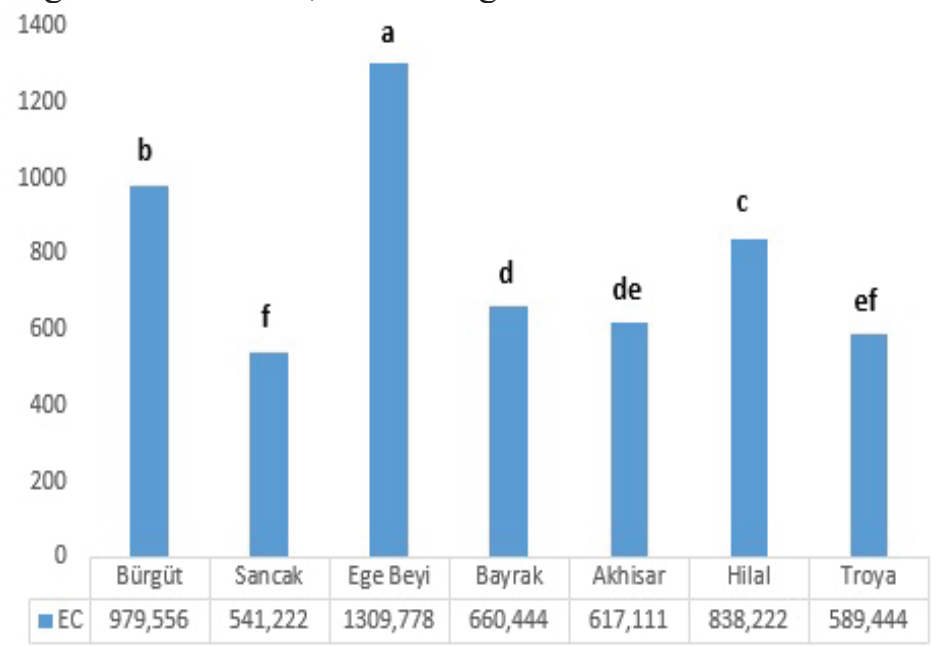

Graph 5. EC ( $\mu \mathrm{S} / \mathrm{cm})$ Values Among Barley Types

Although EC values and the petri test results supported each other, they were partially different from the viol test results. We considered that this was associated with the germination environment difference.

- Protein Contents of the Cultivars

The cultivars were compared before the test in terms of protein contents and no significant difference was determined as a result of the analysis of variance (graph 6). The fact that the protein rates did not make a difference among the cultivars indicated that the differences in the parameters examined were not caused by protein rates. 


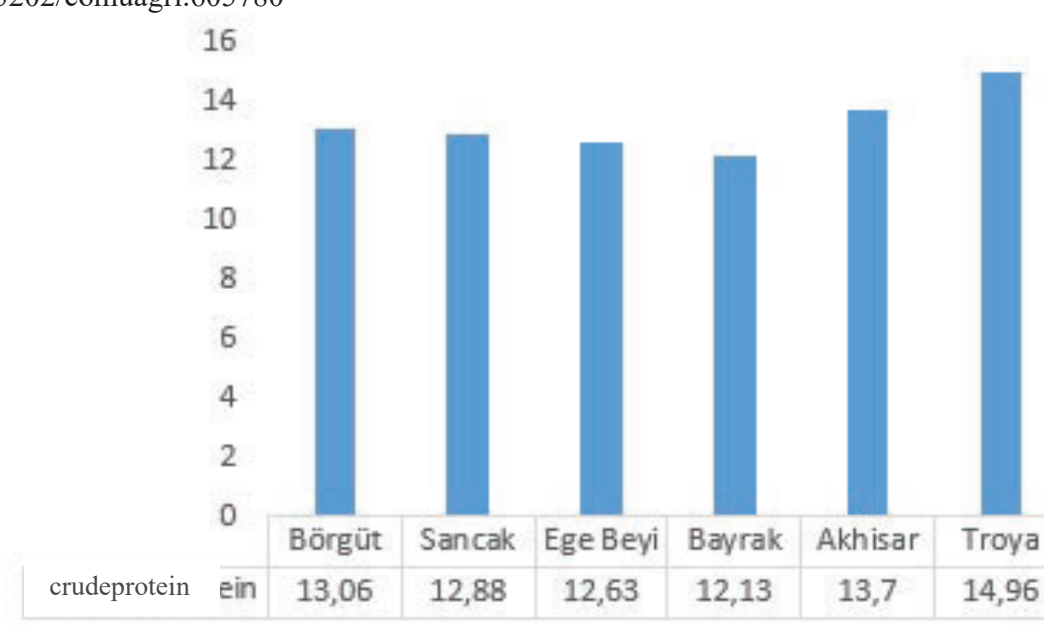

Graph 6. Crude Protein Ratios of Cultivars (\%)

\section{Discussion}

Deterioration in seed is defined as the quality and viability loss due to the effect of negative environmental factors. In both conditions, the increase in the moisture content and storage temperature of seed is directly proportional with the deterioration rate (Ellis et al., 1985). In the present study, the moisture values of the genotypes were found to be between 7.6-10.2\%.The seed deterioration process, storage or viability potential can be determined by the accelerated aging test. Such artificial aging tests demonstrate that this process of seeds is related with the moisture level and temperature. The physiological and biochemical changes during the seed aging are revealed with the seed tests formed for different conditions (Islam et. al, 1973; McDonald, 1999). According to reports by Kapoor et al. (2010) from other researchers, standard procedures about the accelerated aging have been developed for Brassicaceae (Brassica spp.), Maize (Zea mays L.), Lentil (Lens culinaris L.), Chickpea (Cicer arietinum L.), Green Pea (Pisum sativum L.), Cajan Pea (Cajanus cajan L.), Soybean (Gylicine max L.), Mung Bean (Phaseolus mungo L.) and some weeds (Kapoor et. al, 2010).

Soluble protein contents may change in germinated seeds based on the proteinase enzyme activity of barley. In the present study, the crude protein amounts of the genotypes varied between $12.1-14.9 \%$ (Plot 6).Similarly, the estimated starch content in the germinated seeds varied. The quality criteria such as seed size and seed nitrogen $(\mathrm{N})$ concentration affect seedling production and grain yield of cereals (Ries and Everson, 1973). Lowe et al. (1972) and Ries (1971) found that seed protein concentration was positively associated with seedling vigor and yield. The studies on the effect of $\mathrm{P}$ concentration in seeds on plant performance have been conducted recently. Berezkin et al., (1984) stated that higher $\mathrm{P}$ concentration in winter wheat seeds increased seedling growth, but $\mathrm{P}$ was less effective in barley.

Pandey (1990) has reported that the accelerated aging technique is an instrument commonly used to test the seed quality. The accelerated aging test has been suggested as a method to assess the seed storability in the beginning and this test is fast, cheap, simple, and useful for all the species (Copeland and Donald, 2001; Younesi and Moradi, 2009). As the aging process increases in seed, the germination decreases and similar condition was also determined in rapeseed by Ghassemi-Golezani et al. (1996) and in soybean seed by Saha and Sultana (2008). Also, the previous reports (Bailly, 2004; Goel and Sheoran, 2002; McDonald, 2004), indicated that there were negative effects on seed performance, germination percentage and seedling index depending on aging. In our study, seed germination vigor decreased by $10 \%$ during the aging process (graph 3). This result caused differences between genotypes. In aged seeds, the mean germination times had later emergence and germination compared to the control group. (graph 3,4). As a result, Sancak and Troya varieties came to the forefront in terms of germination vigor compared to other varieties. 


\section{Conclusion}

The performance in the use of high quality seed; Firstly, the percentage of green seedlings produced from high quality seeds are more than the low quality seeds and they may be useful to reach the intensity aimed in this field. Secondly, vigorous seeds have higher seedling growth rate and the heterogeneous conditions may be minimized in the germination period (Ghasemi-Golezani,1966). Seed aging is accepted with some parameters such as delay in germination and emergence, slow growth and the increase of the susceptibility to environmental stresses (Walters, 1998).

In this study, the seed deterioration conditions of the seed lots of Hordeum vulgare L. genotypes in three different periods with accelerated aging tests were tried to be determined. As the germination rates of the genotypes were generally high, the comparison with germination rates and times of $2^{\text {nd }}$ day was preferred. Thus, the vigor differences were revealed more clearly.

\section{References}

Allard, R.W, Bradshaw, A.D., 1964. Implications of genotype environmental interactions in applied plant breeding. Crop Science, 4(5): 503-508.

AOAC, 1998. Official Method of Analysis. 15th Edition, Association of Official Analytical Chemists, Washington DC.

Baik, B.K., Ulrich, S.E., 2008. Barley for Food: Characteristics, Improvement, and Renewed Interest. Journal of Cereal Science, 48, 233-242.

Copeland, L.O., McDonald, M.B., 2001. Principles of Seed Science and Technology. Kluwer Academic Publishers, Massachusetts, USA, 467.

Bailly, C., 2004. Active oxygen species and antioxidants in seed biology. Seed Science Research, 14:93-107.

Berezkin, A.N., Guida, V.N., Klochko, N.A., Derezkina, L.L., Dakeev, V.V., 1984. Sowing qualities of barley and winter wheat seeds depend on their phosphorus content. Izvestiya Timiryazevskoi Sel'skokhozyaistvennoi Akademii, 2.

Demir, İ., 1983. Tahıl Islahı. Ege Üniv. Ziraat Fakultesi Yayın No: 235, Ders Kitabı, Ofset Basımevi, Bornova İzmir.

Ellis, R.H., Hong, T.D., Roberts, E.H., Tao, K.L. 1985. Low Moisture Content Limits to Relations Between Seed Longevity and Moisture. Annuals of Botany, Volume 65, Issue 5, 1 May 1990, Pages 493-504.

Ergutay, Z., Elgün, A., 1995. Tahıl işleme teknolojisi. Atatürk Üniversitesi Ziraat Fakültesi, Yayın No: 297 (2.Bask1), s.481. Erzurum.

Ergun, N., Aydogan, S., Sar1, A.O., 2012. Cereal production and agronomic innovation in Turkey. Watch Letter, 23: 36-39.

FAO, 2018. Food and Agriculture Organization of the United Nations

Forster, B.F., Ellis, R.F., Thomas, W.T.B., Newton, A.C., Tuberosa, R., This, D., El-Enein, R.A, Ben, M.H, Salem, M., 2000. The Development and Application of Molecular Markers for Abiotic Stress Tolerance In Barley. Journal of Experimental Botany, 51 (342), 19-27.

Ghasemi-Golezani, K., Salehian, H., Rahimzade-Khoee, F., Moghadam, M., 1966. The effect of seed vigor on seedling emergence and yield of wheat. Natural Resources and Agricultural Sciences, 3: 58-48.

Goel, A.K., Sheoran, I.S, 2002. Changes in oxidative stres enzymes during artificial ageing in cotton (Gossypium hirsutum L.) seeds. Plant Physiology, 160:1093-1100.

Gökgöl, M., 1969. Serin iklim hububatı ziraatı ve sslahı (buğday, çavdar, arpa ve yulaf). Tarım Bakanlığı Ziraat İşleri Genel Müdürlüğ̈̈, 407 s., Özaydın Matbaası, İstanbul.

Harlan, J.R, Zoharry, D., 1966. Distribution of wild wheats and barley. Science 153:1074-1080. DOI: 10.1126.

Islam, A.J.M.A., Delouche, J.C., Baskin, C.C., 1973. Comparison of methods for evaluating geterioration in rice seed. Proceedings of the Association of Official Seed Analysts.

ISTA, 1995. Handbook of Vigour Test Methods. Third Edition, (J.G. Hampton, D. M. TeKrony, editorler) International Seed Testing Association. Zurich, Switzerland.

Kapoor, N., Arya, A., Siddiqui, M.A., Amir, A., Kumar, H., 2010. Seed deterioration in chickpea (Cicer arietinum L.) under accelerated ageing. Asian Journal of Plant Sciences, 9 (3). pp. 158-162.

Kün, E., 1988. Serin iklim tahılları. Ankara Üniversitesi Ziraat Fakültesi Yayınları, No:1032, Ankara.

Lowe, L.B., Ayers, G.S., Ries, S.K., 1972. Relationship of seed protein and amino acid composition to seedling vigor and yield of wheat. Agronomy Joournal 64, 608-6.

McDonald, M.B., 1999. Seed deterioration: physiology, repair and assessment. Seed Science Technology, 27: 177-237.

McDonald, M.B., 2004. Orthodox seed deterioration and its repair. In: Handbook of Seed Physiology: Applications to, 273- $304 \mathrm{pp}$. 
Nesbitt, M., Samuel, D., 1995. From staple crop to extinction. The archaeology and history of the hulled wheats in Hulled Wheats: Proceedings of the First International Workshop on Hulled Wheats, Pascoli, S. Padulosi, K. Hammer and Heller J. eds. IPGRI, Roma, İtalia s. 41-100, 1996.

Pandey, D.K., 1989. Short duration accelerated ageing of French bean seeds in hot water. Seed Science and Technology (Switzerland).17(1):107-114 .

Ries, S.K., 1971. The relationship of size and protein content of bean seed with growth and yield. Journal of the American Society for Horticultural Science 96, 557-560.

Ries, S.K., Everson, E.H., 1973. Protein content and seed size relationship with seedling vigor of wheat cultivars. Agronomy Journal 65, 884-886.

Saha, R.R, Sultana, W., 2008. Influence of seed ageing on growth and yield of soybean. Bangladesh Journal Botany 37(1): 21-26, (June).

Schulte, D., Close, T.J., Graner, A., Langridge, P., Maksumoto, T., Muehlbauer, G., Sato, K., Schulman, A.H., Waugh, R., Wise, R.P., Stein, N., 2009. The International Barley Sequencing Consortium, At the Treshold of Efficient Access to the Barley Genome. Plant Physiology, 149, 142-147.

Sencar, Ö.S., Gökmen, M., 1997. Şeker Mısırın (Zea mays L. var. saccharata Sturt.) Agronomik Özelliklerine Ekim Zamanı ve Yetiştirme Tekniklerinin Etkileri. Doğa Dergisi, 21: 65-71.

Sivritepe, Ö.H., 2012. Tohum Gücünün Değerlendirilmesi. Alatarım 2012, 11 (2): 33-4.

TÜİK, 2015. Türkiye İstatistik kurumu bitkisel üretim verileri. http://www.tuik.gov.tr/PreTablo.do?alt id=1001

TÜİK, 2018. Türkiye İstatistik kurumu bitkisel üretim verileri. http://www.tuik.gov.tr/PreTablo.do?alt id=1001

Younesi, O., Moradi, A., 2009. Effects of Osmo- and Hydro-priming on Seed Parameters of Grain Sorghum (Sorghum bicolor L.). Australian Journal of Basic and Applied Sciences, 3(3): 1696-1700.

Walters, C., 1998. Understanding the mechanisms and kinetics of seed aging. Seed Science Research, 8:223-244. 